\title{
Carbon cycling by microbes influenced by light in the Northeast Atlantic Ocean
}

\author{
Matthew T. Cottrell ${ }^{1}$, Vanessa K. Michelou ${ }^{1}$, Nina Nemcek ${ }^{2,4}{ }^{\text {, Giacomo DiTullio }}{ }^{3}$, \\ David L. Kirchman ${ }^{1, *}$
}

${ }^{1}$ College of Marine and Earth Studies, University of Delaware, Lewes, Delaware 19958, USA

${ }^{2}$ University of British Columbia, Vancouver, British Columbia V6T 1Z4, Canada

${ }^{3}$ College of Charleston, Charleston, South Carolina 29424, USA

${ }^{4}$ Present address: Institute of Ocean Sciences, Sidney, British Columbia V8L 4B2, Canada

\begin{abstract}
The goal of this study was to examine the relationships between phytoplankton and heterotrophic bacteria and the effect of light on bacterial growth and respiration in the Northeast Atlantic Ocean in summer. Heterotrophic microbes were a substantial component of the plankton as indicated by the ratio of bacterial biomass to phytoplankton biomass, which varied from 0.15 to 0.83 , averaging 0.60. Aerobic anoxygenic phototrophic (AAP) bacteria made up on average $10 \%$ of bacterial abundance and $13 \%$ of bacterial biomass. AAP bacterial biomass was on average 2 -fold higher than Synechococcus sp. biomass, whereas Prochlorococcus sp. was never more than $1 \%$ of bacterial biomass. The bacterial production to primary production ratio ranged from 0.04 to 0.14 and was on average 0.07 . The bacterial growth efficiency (BGE) in light incubations $(10 \%)$ was 3 -fold lower than in the dark $(32 \%)$. Consequently, the calculated flux of carbon through bacteria in the light was also about 3-fold lower in the dark, since ratios of bacterial carbon demand (BCD) to primary production inferred from light and dark estimates of BGE were 0.7 and 0.2, respectively. However, BCD and respiration rates were not greater than primary production, suggesting that this region of the North Atlantic was net autotrophic even after the spring bloom. The BGE data and the abundance of photoheterotrophic microbes, such as AAP bacteria, highlight the importance of the effects of light on carbon cycling by bacteria in the Northeast Atlantic Ocean.
\end{abstract}

KEY WORDS: Photoheterotrophy $\cdot$ Light $\cdot$ Respiration $\cdot$ Bacterial growth efficiency $\cdot$ Spring bloom

Resale or republication not permitted without written consent of the publisher

\section{INTRODUCTION}

The North Atlantic spring bloom is one of the most prominent seasonal accumulations of photosynthetic biomass in the ocean, extending thousands of $\mathrm{km}$ north of the Sargasso Sea, into the North Sea and beyond Iceland. This event was exploited by the 1989-1990 North Atlantic Bloom Experiment (NABE) to understand the principal biogeochemical features that characterize carbon and energy cycling in the ocean (Ducklow \& Harris 1993). One substantial contribution of that work was evidence demonstrating the importance of heterotrophic microbes in carbon cycling (Ducklow et al. 1993, 2002, Li et al. 1993). The NABE data were key in estimating the magnitude of heterotrophic bacterial production (BP) relative to primary production (PP) and assessing the role of heterotrophic microbes in processing dissolved organic carbon (DOC) (Kirchman et al. 1991, Fasham et al. 1999).

Despite the opportunities that the North Atlantic spring bloom present for understanding carbon cycling in the ocean, surprisingly few studies have followed up work in the NABE area. In a seasonal study conducted south of the NABE area, Maixandeau et al. (2005) identified the contribution of microbes, including picoautotrophs, bacteria and nanoflagellates, to biological fluxes, and found that the study area was net autotrophic. Morán et al. (2004) examined plankton 
biomass and metabolism in warmer waters to the south of the NABE area. Although BP was $<10 \%$ of PP, community respiration generally exceeded gross PP, suggesting net heterotrophy (Morán et al. 2004). Hoppe et al. (2002) traversed the North and South Atlantic Oceans, including the NABE study area, and identified latitudinal zones of net autotrophy and net heterotrophy, including a region of net heterotrophy between $25^{\circ} \mathrm{N}$ and $30^{\circ} \mathrm{S}$. Waters at higher latitudes, including the NABE region, appeared to be net autotrophic. However, the data were restricted to a single depth at only a few locations in NABE waters. The limited information provided by these studies leaves open questions regarding the net metabolic balance in the NABE study area.

The NABE data were central in the evolution of our understanding of microbial processes in the ocean (Fasham 2003). The initial data indicated that heterotrophic BP was $30 \%$ of PP (BP:PP = 0.3) (Ducklow et al. 1993, Li et al. 1993, Lochte et al. 1993), consistent with other information available at that time from a range of freshwater and coastal marine systems (Cole et al. 1988) as well as modeling studies (Williams 1981). However, the emergence of new data and knowledge necessitated a reformulation of these initial conclusions (Ducklow et al. 2002). The change was precipitated by new assessments of bacterial growth efficiency (BGE), which had been assumed to be $\sim 50 \%$, 3-fold higher than the value of $15 \%$ suggested by new data (del Giorgio \& Cole 1998, Carlson et al. 1999). When the lower estimates of BGE were taken into consideration, it appeared that $\mathrm{BP}$ should be lower relative to $\mathrm{PP}$, and that the BP:PP ratio cannot be higher than 0.15 (Ducklow et al. 2002).

$\mathrm{BP}$ and BGE estimates may have to be assessed again because of new information about the metabolic flexibility of marine microbes, including energy generation and biomass production decoupled from DOC consumption (Moran \& Miller 2007). For example, the discovery of new microbes, such as aerobic anoxygenic phototrophic (AAP) bacteria (Kolber et al. 2000, Cottrell et al. 2006) and proteorhodopsin-containing bacteria (Béjà et al. 2001), suggests that photoheterotrophic metabolism may be widespread in the ocean. There is no consensus regarding the benefits of light harvesting to presumed photoheterotrophic microbes because different cultivated strains have generated conflicting results. For example, studies of cultured AAP bacteria have found both lower (Koblizek et al. 2003) and higher DOC uptake in the light (Cooney et al. 2006). Similarly, the effects of light on cultivated proteorhodopsin-containing bacteria range from demonstrable growth stimulation in the light (Gomez-Consarnau et al. 2007) to no detectable difference (Giovannoni et al. 2005, Stingl et al. 2007). Few studies have directly examined how light affects BGE in natural settings (Pakulski et al. 1998).

The goal of the present study was to examine relationships between auto- and heterotrophic processes and the effect of light on carbon cycling in the Northeast Atlantic Ocean. We measured BP, bacterial respiration, BGE and PP between 45 and $60^{\circ} \mathrm{N}$ during the North Atlantic Spring Bloom (NASB) expedition in 2005. Estimates of bacterial carbon demand (BCD) were compared to PP to examine metabolic balance. The effect of light on BGE and the abundance of AAP bacteria were assessed to evaluate the potential importance of light effects on carbon cycling in the Northeast Atlantic Ocean.

\section{MATERIALS AND METHODS}

Water column measurements. PP and BP were measured at 17 sampling locations during the NASB transect in summer 2005. Sampling was conducted between latitudes of approximately 45 and $60^{\circ} \mathrm{N}$ and longitudes of 15 and $20^{\circ} \mathrm{W}$ (Fig. 1). PP rates were estimated as described previously (DiTullio et al. 2003). In brief, uptake rates of ${ }^{14} \mathrm{CO}_{2}$ were determined in $24 \mathrm{~h}$ incubations that simulated light intensities and spectra at 6 optical depths in the water column. The incuba-

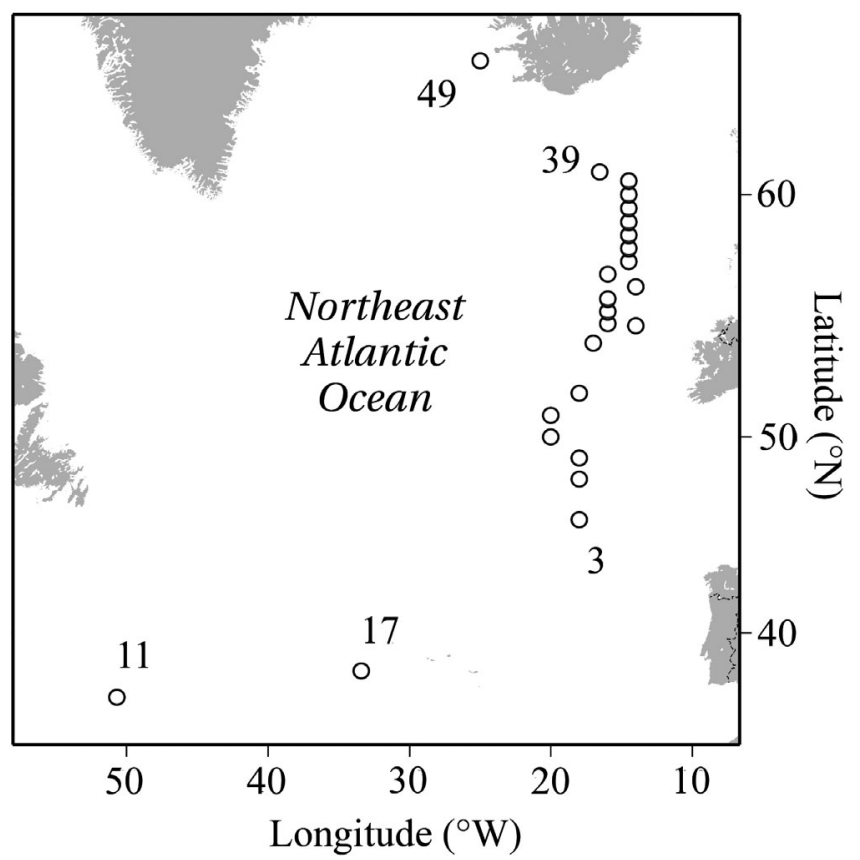

Fig. 1. Locations sampled in the central North Atlantic and Northeast Atlantic during the North Atlantic Spring Bloom expedition in summer 2005. Selected station numbers are indicated 
tions were in a flow-through system with surface seawater. After the incubation, particulate material was collected by filtering the entire $250 \mathrm{ml}$ of incubated seawater onto a GF/F filter (Whatman), rinsed with $0.2 \mu \mathrm{m}$ filtered seawater to remove unincorporated ${ }^{14} \mathrm{C}$ and acidified with $1 \mathrm{ml}$ of $50 \%$ phosphoric acid to remove inorganic carbon. The filters were then radioassayed to determine ${ }^{14} \mathrm{C}$ uptake.

Chlorophyll a (chl a) was measured by fluorometry using $90 \%$ acetone extracts of particulate material collected on GF/F filters (Parsons et al. 1984). Phytoplankton biomass was estimated using a ratio of $40 \mathrm{~g} \mathrm{C} \mathrm{g}^{-1}$ chl a (Geider 1987).

BP was estimated from leucine incorporation rates measured by standard methods (Kirchman 2001). Unless indicated otherwise, all estimates discussed here are from dark incubations. Triplicate samples with ${ }^{3} \mathrm{H}$-leucine $\left(20 \mathrm{nmol} \mathrm{l}^{-1}\right)$ were incubated for $2 \mathrm{~h}$ at the in situ temperature. The incorporated ${ }^{3} \mathrm{H}$-leucine was precipitated by trichloroacetic acid (TCA), collected by centrifugation and then rinsed with TCA and ethanol. The samples were then dried and radioassayed to determine ${ }^{3} \mathrm{H}$-leucine uptake. Killed controls were poisoned with TCA. A conversion factor of $1.5 \mathrm{~kg} \mathrm{C} \mathrm{mol}{ }^{-1}$ of incorporated leucine was used to calculate biomass production. This factor assumes that isotope dilution is zero and thus is the lowest possible theoretical factor (Kirchman 2001).

Bacterial abundance was determined using paraformaldehyde-fixed samples that were filtered onto $0.2 \mu \mathrm{m}$ pore-size black polycarbonate filters (Porter \& Feig 1980) and then stained with a solution containing $1 \mu \mathrm{g} \mathrm{ml}^{-1}$ DAPI in a Tris buffer containing $0.5 \mathrm{M} \mathrm{NaCl}$. The filter was mounted on a glass slide with a cover slip and bacteria were enumerated by epifluorescence microscopy using semi-automated image analysis (Cottrell \& Kirchman 2003).

AAP bacteria were enumerated using a computercontrolled microscope (Olympus Provis AX70) and image analysis (ImagePro Plus, Media Cybernetics) following the procedure described by Cottrell et al. (2006). A series of 4 images was acquired for each field of view using the following optical filter sets: DAPI (excitation $360 \pm 40 \mathrm{~nm}$, emission $460 \pm 50 \mathrm{~nm}$ ), infrared $(390 \pm 100 \mathrm{~nm}, 750 \mathrm{~nm}$ long pass), chl a (480 \pm $30 \mathrm{~nm}, 660 \pm 50 \mathrm{~nm}$ ) and phycoerythrin (545 $\pm 30 \mathrm{~nm}$, $610 \pm 75 \mathrm{~nm}$ ) (Chroma). Cells were identified by detecting edges with Laplacian and Gaussian filters applied in series (Massana et al. 1997). The filtered images were segmented into binary format and then overlaid to identify AAP bacteria, which have DAPI and infrared fluorescence but not chl a or phycoerythrin fluorescence. AAP bacterial biomass was estimated from AAP bacterial abundance, assuming $12.4 \mathrm{fg} \mathrm{C} \mathrm{Cell}^{-1}$ (Fukuda et al. 1998).
Seawater samples for enumeration of Synechococcus sp. and Prochlorococcus sp. were preserved with $2 \%$ paraformaldehyde, frozen in liquid nitrogen and stored at $-20^{\circ} \mathrm{C}$ until analysis. Analyses were performed with a FACSCalibur (Becton-Dickinson) flow cytometer using $488 \mathrm{~nm}$ laser excitation and $0.2 \mu \mathrm{m}$ filtered sheath fluid prepared with deionized water and $40 \mathrm{~g} \mathrm{l}^{-1} \mathrm{NaCl}$. Synechococcus sp. and Prochlorococcus sp. were identified in plots of red (>640 nm) versus orange (560 to $640 \mathrm{~nm}$ ) fluorescence and red fluorescence versus side scatter, respectively (Campbell 2001). Counts were calibrated using flow rates determined by weighing samples before and after analysis. Consistency of flow rates, fluorescence and side scatter were monitored using $1 \mu \mathrm{m}$ diameter fluorescent beads (Molecular Probes, F-8823) added to samples. Synechococcus sp. and Prochlorococcus sp. biomass was calculated from cell abundance assuming $100 \mathrm{fg} \mathrm{C}$ cell $^{-1}$ for Synechococcus sp. and $29 \mathrm{fg} \mathrm{C} \mathrm{cell}^{-1}$ for Prochlorococcus sp. (Zubkov et al. 2000).

Incubation experiments. BGE was calculated from rates of bacterial biomass production and respiration measured in $0.8 \mu \mathrm{m}$ filtered (polycarbonate, Poretics) seawater exposed to sunlight and held in the dark. Incubations were conducted in biological oxygen demand (BOD) bottles (Wheaton) placed in a deck incubator supplied with surface seawater. The incubator was covered by a clear acrylic sheet (Plexiglas XT colorless, 3 mm thick, Rohm \& Haas), which blocks all UV-B and partially screens out UV-A irradiance (50\% transmission at $375 \mathrm{~nm}$ ) (data not shown). The light treatment bottles were covered with neutral density screening passing $30 \%$ of incident irradiance. Black plastic was used to exclude light from the dark incubations. Three bottles were sacrificed for oxygen and bacterial abundance measurements every $12 \mathrm{~h}$ for $48 \mathrm{~h}$.

Bacterial biomass production in the experiments was determined from the slope of the linear regression of bacterial abundance versus time. Bacterial biomass production was estimated assuming $12.4 \mathrm{fg} \mathrm{C} \mathrm{Cell}^{-1}$ (Fukuda et al. 1998).

Bacterial respiration was measured by monitoring changes in oxygen concentrations calculated by Winkler titration using a potentiometric electrode and automated endpoint detection (Metrohm Titrino 785, Brinkmann Instruments) (Preen \& Kirchman 2004). Volumetric respiration $\left(\mathrm{mmol} \mathrm{O}_{2} \mathrm{~m}^{-3} \mathrm{~d}^{-1}\right.$ ) rates were calculated using linear regression of oxygen concentration versus time. Changes in oxygen concentrations never deviated substantially from linearity. Respiration rates were converted from oxygen consumed to carbon respired by assuming a respiratory quotient of 1 (Rodrigues \& Williams 2001). BGE was calculated as: bacterial biomass production/(bacterial biomass production + bacterial respiration). 
Depth integration and estimation of uncertainties. Integrated standing stocks and rates were calculated from the surface to the depth receiving $1 \%$ of surface irradiance. Errors on calculated values such as integrated rates and BGEs were estimated using standard propagation of error techniques (Valiela 2001). In brief, the errors on sums were calculated by adding up the variances of the terms in the sum. Similarly, the errors on quotients were estimated by summing the relative variances.

\section{RESULTS}

The NASB transect was designed to examine phytoplankton and bacterial processes in a range of water types. Surface water temperatures varied from 16.0 to $10.8^{\circ} \mathrm{C}$ between Stns 3 and 9 at approximately 45 and $60^{\circ} \mathrm{N}$, respectively (Table 1 ). Cooler waters with a surface temperature of $9.7^{\circ} \mathrm{C}$ were sampled at Stn 49 at approximately $64^{\circ} \mathrm{N}$, located far north of the other stations. In contrast, stations in the central North Atlantic were in a warmer water mass with a surface temperature of $\sim 20^{\circ} \mathrm{C}$. A 4 -fold variation in photic zone depth also revealed differences in the waters sampled. The clearest water had a photic zone depth of $100 \mathrm{~m}$ at

Table 1. Sea surface temperature (SST) and photic zone depth (PZ) at selected stations. PZ corresponds to the $1 \%$ light depth. SST was determined at $5 \mathrm{~m}$. nd $=$ not determined

\begin{tabular}{|c|c|c|c|c|c|}
\hline Stn & Date (2005) & Lat. (N) & Long. (W) & $\mathrm{SST}\left({ }^{\circ} \mathrm{C}\right)$ & $\mathrm{PZ}(\mathrm{m})$ \\
\hline \multicolumn{6}{|c|}{ Central North Atlantic } \\
\hline 11 & May 28 & $36^{\circ} 20.56^{\prime}$ & $51^{\circ} 18.88^{\prime}$ & 20.8 & nd \\
\hline 17 & May 31 & $37^{\circ} 52.84^{\prime}$ & $34^{\circ} 34.84^{\prime}$ & 19.3 & nd \\
\hline \multicolumn{6}{|c|}{ Northeast Atlantic } \\
\hline 3 & Jun 7 & $45^{\circ} 59.97^{\prime}$ & $19^{\circ} 59.96^{\prime}$ & 16.0 & 100 \\
\hline 5 & Jun 8 & $48^{\circ} 0.01^{\prime}$ & $19^{\circ} 59.93^{\prime}$ & 15.0 & 100 \\
\hline 6 & Jun 8 & $49^{\circ} 1.72^{\prime}$ & $19^{\circ} 59.97^{\prime}$ & 14.7 & 42 \\
\hline 7 & Jun 9 & $50^{\circ} 0.03^{\prime}$ & $20^{\circ} 0.04^{\prime}$ & 13.7 & 55 \\
\hline 10 & Jun 10 & $50^{\circ} 59.90^{\prime}$ & $20^{\circ} 0.06^{\prime}$ & 13.3 & 55 \\
\hline 13 & Jun 11 & $52^{\circ} 0.01^{\prime}$ & $19^{\circ} 59.99^{\prime}$ & 13.3 & 45 \\
\hline 14 & Jun 12 & $54^{\circ} 10.61^{\prime}$ & $17^{\circ} 0.24^{\prime}$ & 13.3 & 45 \\
\hline 16 & Jun 13 & $55^{\circ} 0.15^{\prime}$ & $16^{\circ} 0.00^{\prime}$ & 13.4 & 25 \\
\hline 18 & Jun 14 & $54^{\circ} 54.96^{\prime}$ & $15^{\circ} 59.94^{\prime}$ & 13.4 & 30 \\
\hline 19 & Jun 15 & $55^{\circ} 30.00^{\prime}$ & $16^{\circ} 0.16^{\prime}$ & 11.1 & 30 \\
\hline 21 & Jun 16 & $56^{\circ} 0.01^{\prime}$ & $16^{\circ} 0.02^{\prime}$ & 11.9 & 45 \\
\hline 23 & Jun 17 & $56^{\circ} 30.00^{\prime}$ & $15^{\circ} 59.99^{\prime}$ & 12.3 & 40 \\
\hline 25 & Jun 18 & $57^{\circ} 0.04^{\prime}$ & $16^{\circ} 0.00^{\prime}$ & 11.7 & 40 \\
\hline 26 & Jun 18 & $57^{\circ} 30.07^{\prime}$ & $15^{\circ} 29.92^{\prime}$ & 11.7 & 26 \\
\hline 27 & Jun 19 & $58^{\circ} 0.11^{\prime}$ & $15^{\circ} 30.06^{\prime}$ & 11.3 & 30 \\
\hline 29 & Jun 20 & $58^{\circ} 29.94^{\prime}$ & $15^{\circ} 29.84^{\prime}$ & 11.1 & 30 \\
\hline 31 & Jun 21 & $59^{\circ} 0.05^{\prime}$ & $15^{\circ} 29.84^{\prime}$ & 11.5 & nd \\
\hline 32 & Jun 22 & $59^{\circ} 29.95^{\prime}$ & $15^{\circ} 30.10^{\prime}$ & 11.1 & 20 \\
\hline 34 & Jun 23 & $59^{\circ} 59.96^{\prime}$ & $15^{\circ} 30.13^{\prime}$ & 10.5 & 30 \\
\hline 36 & Jun 24 & $60^{\circ} 29.95^{\prime}$ & $15^{\circ} 30.09^{\prime}$ & 10.7 & 30 \\
\hline 39 & Jun 25 & $60^{\circ} 49.04^{\prime}$ & $17^{\circ} 26.74^{\prime}$ & 10.8 & nd \\
\hline 49 & Jun 30 & $64^{\circ} 29.98^{\prime}$ & $25^{\circ} 00.12^{\prime}$ & 9.7 & nd \\
\hline
\end{tabular}

Stns 3 and 5, which were located furthest south. At the more northerly stations, photic zone depths ranged from 25 to $55 \mathrm{~m}$ (average $37 \pm 11 \mathrm{~m}$ ) (Table 1).

\section{Standing stocks of phytoplankton and bacteria}

On average archaea made up only $10 \%$ of the prokaryotes in the waters considered here (data not shown), so we use 'bacteria' when referring to prokaryotic microbes. Integrated standing stocks of chl a in the Northeast Atlantic varied 3-fold, from 16.9 to $57.0 \mathrm{mg}$ chl a m $\mathrm{m}^{-2}$ (Table 2). The standing stock of phytoplankton biomass determined from chlorophyll averaged $1.30 \pm 0.47 \mathrm{mg} \mathrm{C} \mathrm{m}^{-2}$ and the standing stock of bacterial biomass averaged $0.70 \pm 0.18 \mathrm{mg} C$ $\mathrm{m}^{-2}$. The ratio of bacterial biomass to phytoplankton biomass ranged from 0.15 to 0.83 (average $0.60 \pm$ 0.20 ). Phytoplankton biomass and bacterial biomass were not significantly correlated $(\mathrm{r}=-0.0062, \mathrm{p}>$ $0.05, \mathrm{n}=17$ ).

Total bacterial biomass was constant, ranging from 1.0 to $1.6 \mathrm{~g} \mathrm{C} \mathrm{m}^{-2}$ (average $1.2 \pm 0.2 \mathrm{~g} \mathrm{C} \mathrm{m}^{-2}$ ) (Fig. 2A), whereas the contribution of AAP bacteria and Synechococcus sp. to bacterial biomass was variable. Synechococcus sp. biomass varied almost 20-fold, ranging from 1.3 to $28 \%$ of total bacterial biomass, an average of ca. $9 \%$ (Fig. 2B). AAP bacterial biomass rivaled that of Synechococcus sp., and made up as much as $23 \%$ of total bacterial biomass (average of $13 \%$ ). However, AAP bacteria were not always abundant and in some locations contributed as little as $5 \%$ of total bacterial biomass (Fig. 2C). Nevertheless, AAP bacterial biomass, as well as Synechococcus sp. biomass, was always greater than Prochlorococcus sp. biomass, which never was more than $2 \%$ of total bacterial biomass (Fig. 2B). Latitudinal variations in the contributions of Synechococcus sp. and AAP bacteria to bacterial biomass were similar. Percentage AAP bacterial biomass and Synechococcus sp. biomass were significantly correlated $(\mathrm{r}=0.51, \mathrm{p}<0.05, \mathrm{n}=17)$ and the percentage of bacterial biomass in both groups decreased north of about $50^{\circ} \mathrm{N}$ (Fig. 2B,C). Similar to the relative contributions to the bacterial community, the absolute abundances of AAP bacteria and Synechococcus sp. were correlated, albeit only weakly $(\mathrm{r}=0.25$, $\mathrm{p}<0.05, \mathrm{n}=107$ ). 


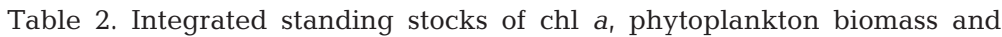
bacterial biomass in the Northeast Atlantic

\begin{tabular}{|lcccc|}
\hline Stn & $\begin{array}{c}\text { Chl } a \\
\left(\mathrm{mg} \mathrm{m}^{-2}\right)\end{array}$ & $\begin{array}{c}\text { Phytoplankton } \\
\text { biomass } \\
\left(\mathrm{g} \mathrm{C} \mathrm{m}^{-2}\right)\end{array}$ & $\begin{array}{c}\text { Bacterial } \\
\text { biomass } \\
\left(\mathrm{g} \mathrm{C} \mathrm{m}^{-2}\right)\end{array}$ & $\begin{array}{c}\text { Bacterial: } \\
\text { phytoplankton } \\
\text { biomass ratio }\end{array}$ \\
\hline 3 & $22.5 \pm 1.1$ & $0.87 \pm 0.04$ & $0.74 \pm 0.08$ & 0.85 \\
5 & $29.0 \pm 1.0$ & $1.16 \pm 0.04$ & $0.90 \pm 0.15$ & 0.78 \\
7 & $27.4 \pm 1.2$ & $1.10 \pm 0.05$ & $0.66 \pm 0.10$ & 0.60 \\
10 & $25.2 \pm 0.7$ & $1.01 \pm 0.03$ & $0.84 \pm 0.15$ & 0.83 \\
13 & $26.1 \pm 3.3$ & $1.04 \pm 0.13$ & $0.84 \pm 0.19$ & 0.81 \\
14 & $24.4 \pm 0.8$ & $0.98 \pm 0.03$ & $0.82 \pm 0.11$ & 0.84 \\
16 & $25.7 \pm 0.7$ & $1.03 \pm 0.02$ & $0.59 \pm 0.07$ & 0.57 \\
18 & $19.6 \pm 0.6$ & $0.78 \pm 0.03$ & $0.51 \pm 0.07$ & 0.65 \\
19 & $16.9 \pm 0.6$ & $0.68 \pm 0.02$ & $0.39 \pm 0.09$ & 0.57 \\
21 & $26.8 \pm 0.9$ & $1.07 \pm 0.04$ & $0.77 \pm 0.16$ & 0.71 \\
23 & $34.0 \pm 1.0$ & $1.36 \pm 0.04$ & $0.85 \pm 0.24$ & 0.62 \\
25 & $33.8 \pm 1.8$ & $1.35 \pm 0.07$ & $0.64 \pm 0.13$ & 0.47 \\
27 & $41.8 \pm 1.2$ & $1.67 \pm 0.05$ & $0.89 \pm 0.18$ & 0.53 \\
29 & $40.2 \pm 1.3$ & $1.61 \pm 0.05$ & $0.67 \pm 0.15$ & 0.42 \\
32 & $57.0 \pm 5.2$ & $2.28 \pm 0.21$ & $0.34 \pm 0.06$ & 0.15 \\
34 & $52.6 \pm 1.4$ & $2.10 \pm 0.06$ & $0.97 \pm 0.25$ & 0.46 \\
36 & $48.6 \pm 1.5$ & $1.95 \pm 0.06$ & $0.56 \pm 0.14$ & 0.29 \\
\hline
\end{tabular}

In addition to being a large component of bacterial biomass, AAP bacteria were also numerically abundant in the central North Atlantic and Northeast Atlantic. AAP bacteria made up on average $10 \pm 12 \%$ of the bacterial community in waters within the photic zone. AAP bacterial abundance typically decreased with depth to abundances $<2 \%$ of the bacteria at $100 \mathrm{~m}$ (Fig. 3). In the central North Atlantic, bacterial communities at Stns 11 and 17 included 3 and $9 \%$ AAP bacteria, respectively (data not shown).

\section{Primary production and heterotrophic metabolism}

Integrated rates of PP in the Northeast Atlantic varied 2.5-fold, from 352 to 893 mg C m${ }^{-2} \mathrm{~d}^{-1}$ (average $620 \pm 181 \mathrm{mg} \mathrm{C}$
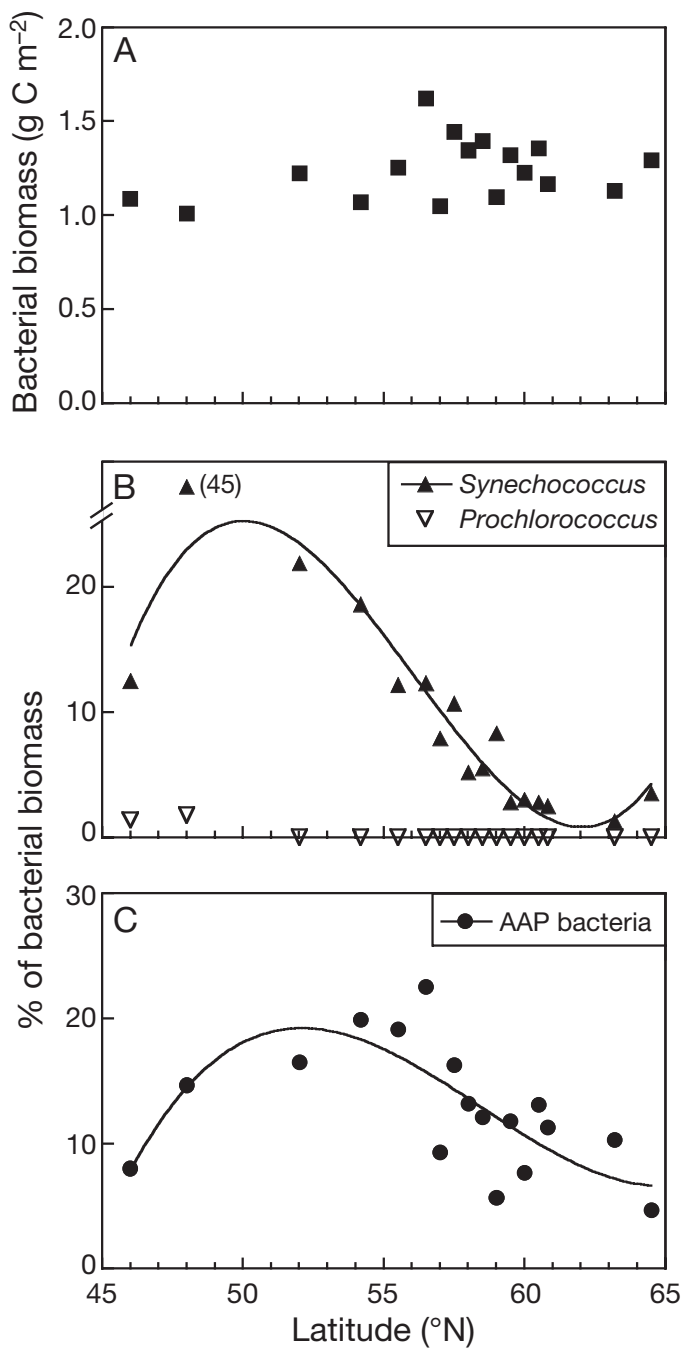

$\mathrm{m}^{-2} \mathrm{~d}^{-1}$ ). Rates of PP were highest (750 $\mathrm{mg} \mathrm{C} \mathrm{m}^{-2} \mathrm{~d}^{-1}$ ) at the lowest and highest latitudes (Fig. 4A) and were lowest $\left(<500 \mathrm{mg} \mathrm{C} \mathrm{m}^{-2} \mathrm{~d}^{-1}\right)$ at intermediate latitudes between 52 and $55^{\circ} \mathrm{N}$.

Both BP and bacterial respiration varied substantially, more so than PP in the Northeast Atlantic. BP varied 3.5-fold from 19.3 to $68.3 \mathrm{mg} \mathrm{C} \mathrm{m}^{-2} \mathrm{~d}^{-1}$ (average $40.6 \pm 11.5 \mathrm{mg} \mathrm{C} \mathrm{m}^{-2} \mathrm{~d}^{-1}$ ) (Fig. 4B). These estimates were determined from dark incubations; leucine incorporation in light and dark incubations did not differ substantially in this region of the Northeast Atlantic, but light significantly stimulated leucine incorporation in samples from lower latitude stations occupied by NASB (Michelou et al. 2007). Similar to PP, BP was greatest at the lowest and highest latitudes. BP was $>50 \mathrm{mg} \mathrm{C} \mathrm{m}^{-2} \mathrm{~d}^{-1}$ south of $52^{\circ} \mathrm{N}$ and north of $60^{\circ} \mathrm{N}$, and was lowest $\left(\sim 25 \mathrm{mg} \mathrm{C} \mathrm{m}^{-2} \mathrm{~d}^{-1}\right)$ at intermediate latitudes between 54 and $56^{\circ} \mathrm{N}$. The ratio BP:PP ranged from 0.04 to 0.14 , averaging $0.07 \pm 0.03$ (Fig. 4C). BP and PP were not significantly correlated $(r=0.25, p>0.05$, $\mathrm{n}=17)$. Bacterial respiration varied approximately 5-fold from 101 to $502 \mathrm{mg} \mathrm{C} \mathrm{m} \mathrm{d}^{-1}$ (Table 3). In contrast, PP ranged about 2-fold from 470 to $1101 \mathrm{mg} \mathrm{C}$ $\mathrm{m}^{-2} \mathrm{~d}^{-1}$. The ratio of bacterial respiration to PP in the North Atlantic ranged from 0.14 to 0.56 and overall averaged 0.39 .

Fig. 2. (A) Integrated total bacterial biomass and the percentage of bacterial biomass contributed by (B) Synechococcus sp. and Prochlorococcus sp. and (C) aerobic anoxygenic phototrophic (AAP) bacteria. The lines were generated by nonlinear regression 


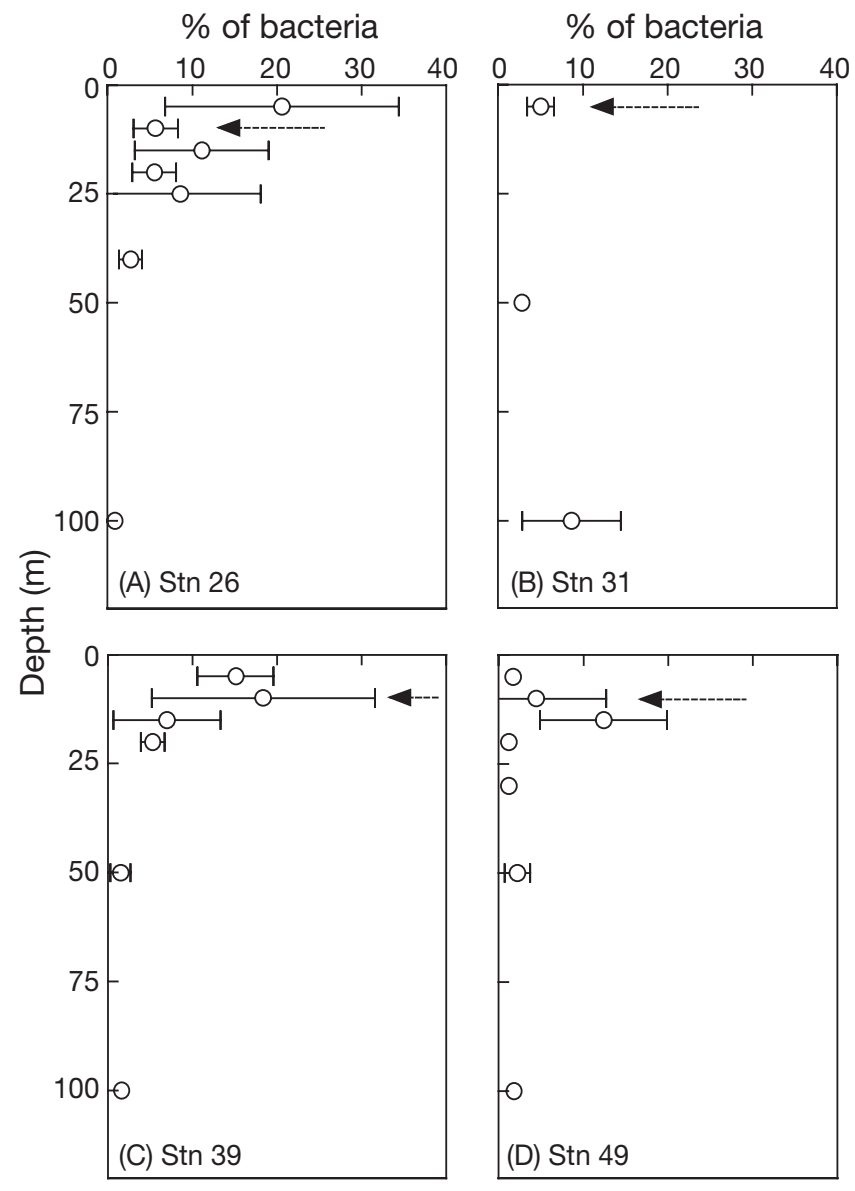

Fig. 3. Abundance of AAP bacteria as a percentage of total bacteria in the Northeast Atlantic. Arrows indicate the depths - $10 \mathrm{~m}$ at Stn 26 (A), Stn 39 (C) and Stn 49 (D) and $5 \mathrm{~m}$ at Stn 31 (B) - where bacterial growth efficiency was measured. Error bars are the SD of 10 microscopic fields of view

\section{Effects of light on growth and respiration}

Light had a substantial effect on respiration, but not on biomass production in incubations of the bacterial size fraction (Fig. 5) or of the whole community (Michelou et al. 2007). Rates of oxygen consumption in light incubations were 1.6-fold higher than in dark incubations (paired $t$-test, $\mathrm{p}<0.05, \mathrm{n}=7$ ). Respiration in the light was always higher than in the dark, although the difference was significant at only 2 locations (Fig. 5A). The difference between oxygen consumption in light and dark incubations averaged $0.042 \pm 0.025 \mu \mathrm{mol} \mathrm{O}_{2}$ $\mathrm{l}^{-1} \mathrm{~h}^{-1}$. In contrast, there was no consistent effect of light on bacterial growth (paired $t$-test, $\mathrm{p}=0.39, \mathrm{n}=7$ ). Growth was significantly higher in the light at one location and significantly higher in the dark at another location, and the 2 incubations did not differ significantly at the other locations (Fig. 5B).
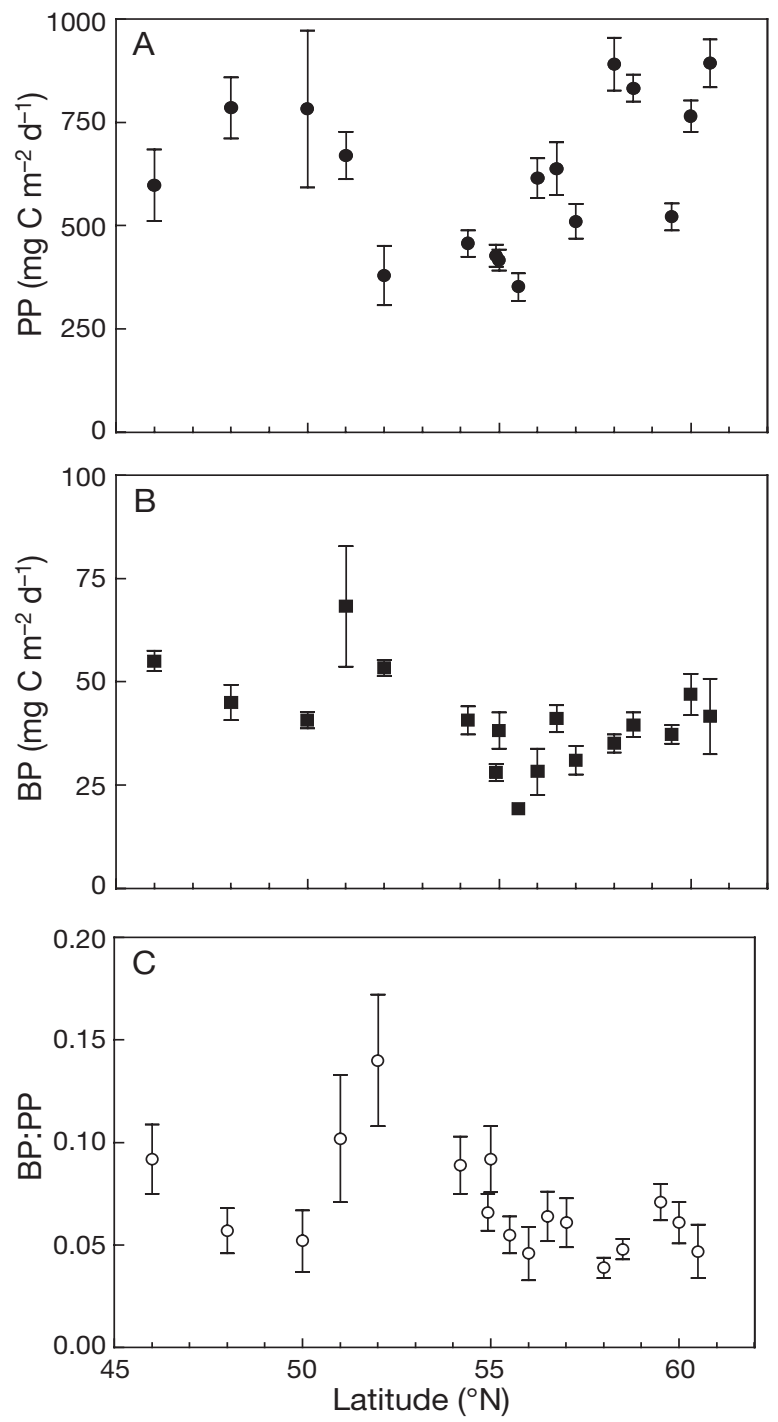

Fig. 4. (A) Integrated primary production (PP), (B) bacterial production $(\mathrm{BP})$, and $(\mathrm{C})$ the ratio $\mathrm{BP}: \mathrm{PP}$ measured in the Northeast Atlantic. Errors were calculated by propagating the errors in volumetric rates

Table 3. Comparison of primary production (PP) and bacterial respiration (R). Integrated rates of respiration were calculated assuming uniform respiration throughout the photic zone. Values are averages for the indicated latitude interval. Errors are SD of measurements made at 3 to 5 locations for PP and 2 locations for $\mathrm{R}$, except for the $45-50^{\circ}$ interval, where only a single respiration measurement was made. nd $=$ not determined

\begin{tabular}{|cccc|}
\hline Lat. $\left({ }^{\circ} \mathrm{N}\right)$ & $\begin{array}{c}\mathrm{PP} \\
\left(\mathrm{mg} \mathrm{C} \mathrm{m}^{-2} \mathrm{~d}^{-1}\right)\end{array}$ & $\begin{array}{c}\mathrm{R} \\
\left(\mathrm{mg} \mathrm{C} \mathrm{m}^{-2} \mathrm{~d}^{-1}\right)\end{array}$ & $\mathrm{R}: \mathrm{PP}$ \\
\hline $45-50$ & $722 \pm 107$ & $101 \pm 172$ & 0.14 \\
$50-55$ & $470 \pm 115$ & nd & nd \\
$55-60$ & $538 \pm 211$ & $302 \pm 254$ & 0.56 \\
$60-65$ & $1101 \pm 476$ & $502 \pm 303$ & 0.46 \\
\hline
\end{tabular}



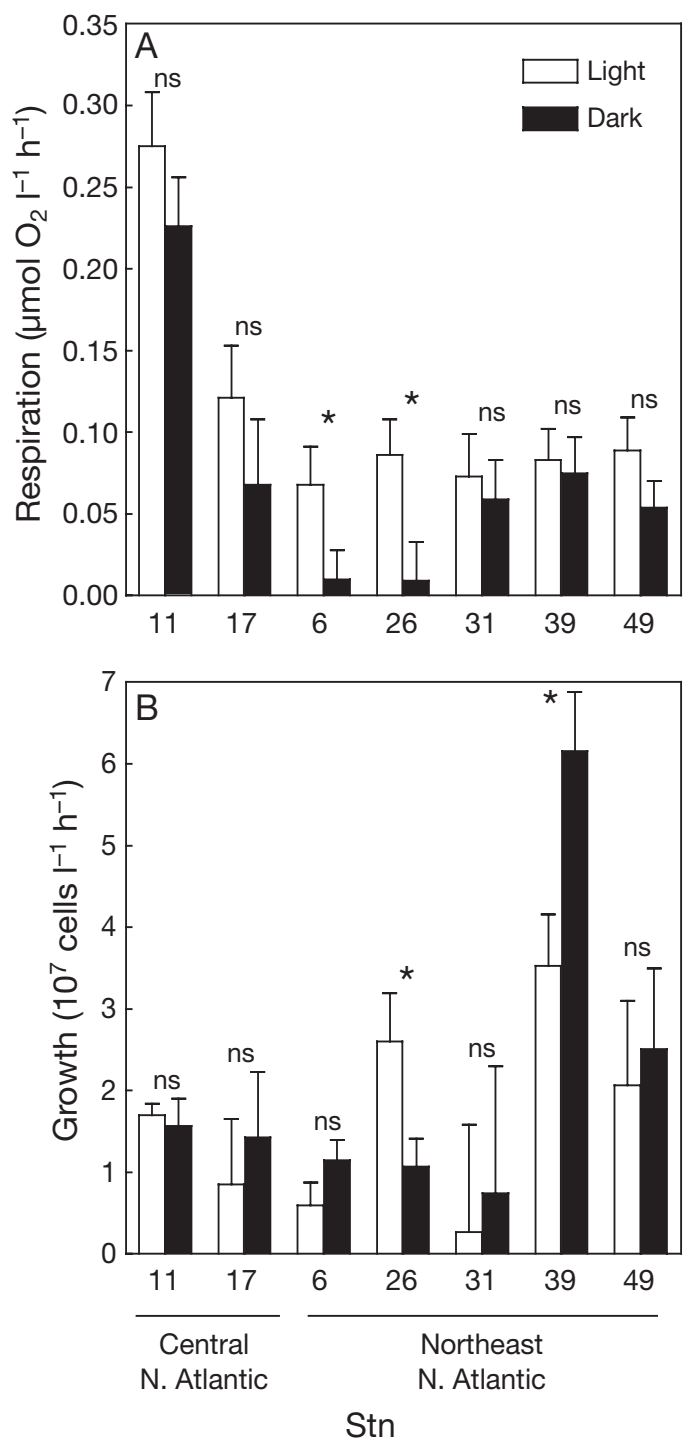

Fig. 5. (A) Bacterial respiration and (B) bacterial growth measured in the central North Atlantic and Northeast Atlantic. Assays were conducted in the dark and in the light. Error bars are $+\mathrm{SD}$

Light also had a significant effect on BGE. Growth efficiencies measured in the light were 3 -fold lower than those measured in the dark (paired $t$-test, $\mathrm{p}<$ $0.05, \mathrm{n}=7$ ), averaging $10 \pm 11$ and $32 \pm 20 \%$, respectively (Table 4).

$\mathrm{BCD}$, which is BP divided by BGE, was calculated using BP measured in the dark and estimates of BGE obtained in the light and in the dark. BCD calculated using the $10 \%$ BGE determined in the light ranged from 196 to $683 \mathrm{mg} \mathrm{C} \mathrm{m}^{-2} \mathrm{~d}^{-1}$ (average $393 \pm 114 \mathrm{mg} \mathrm{C}$ $\mathrm{m}^{-2} \mathrm{~d}^{-1}$ ) (Fig. 6A), whereas the estimate was lower, ranging from 60 to $213 \mathrm{mg} \mathrm{C} \mathrm{m}^{-2} \mathrm{~d}^{-1}$ (average $123 \pm$ $36 \mathrm{mg} \mathrm{C} \mathrm{m}^{-2} \mathrm{~d}^{-1}$ ) when calculated using the $32 \%$ BGE measured in the dark. The light effect on BCD was
$<1 \%$ when BCD was calculated using BP measured in the light (data not shown). BCD was typically less than PP whether calculated using estimates of BGE obtained in the light or in the dark. Using the higher estimates of BCD obtained in the light, the ratio of BCD:PP ranged from 0.4 to 1.4 , averaging $0.7 \pm 0.3$ (Fig. 6B). In contrast, the ratio of $\mathrm{BCD}: \mathrm{PP}$ was always $<0.4$, averaging $0.2 \pm 0.1$ when the dark BGE values were used.

\section{DISCUSSION}

The NASB expedition in summer 2005 was an opportunity to bring new data to bear on issues concerning the relationship between BP and PP that were raised over a decade earlier during the NABE experiment (Ducklow \& Harris 1993). There were obvious differences in the 2 studies, including timing and location of sampling, that complicate direct comparison of results. However, revisiting the NABE area enabled us to obtain another sample of the bacterial and phytoplankton processes operating in the Northeast Atlantic and to assess these data in light of advances in knowledge gained over the last $10 \mathrm{yr}$.

The accumulation of phytoplankton biomass is the main manifestation of the bloom, which begins in late March to April in the western Atlantic and then develops further east and north until peaking after about 1 or 2 mo (Li et al. 1993). The NASB sampling occurred between May 28 and June 30, a time period likely to encompass post-bloom conditions. Data on phytoplankton standing stocks confirm that the peak of the bloom had passed. Photic zone standing stocks of phytoplankton were much higher in NABE than in NASB $\left(1.3 \pm 0.5\right.$ and $5.5 \mathrm{~g} \mathrm{C} \mathrm{m}^{-2}$ in NASB and NABE, respectively) (Ducklow et al. 1993). Similarly, phyto-

Table 4. Bacterial growth efficiency (BGE) measured in light and dark incubations. SEs were calculated by propagating the uncertainties in rates of biomass production (average $\mathrm{CV}=9.6 \%$ ) and oxygen consumption (average $\mathrm{CV}=52 \%$ )

\begin{tabular}{|c|c|c|c|c|}
\hline \multirow[t]{2}{*}{ Stn } & \multicolumn{2}{|c|}{ Light } & \multicolumn{2}{|c|}{ Dark } \\
\hline & BGE $(\%)$ & SE & BGE (\%) & SE \\
\hline \multicolumn{5}{|c|}{ Central North Atlantic } \\
\hline 11 & 6.0 & 1.2 & 6.7 & 2.3 \\
\hline 17 & 6.7 & 8.5 & 17.8 & 20.4 \\
\hline \multicolumn{5}{|c|}{ Northeast Atlantic } \\
\hline 6 & 8.2 & 6.8 & 53.2 & 60.4 \\
\hline 26 & 23.9 & 11.3 & 54.0 & 90.2 \\
\hline 31 & 3.7 & 19.8 & 11.6 & 31.3 \\
\hline 39 & 30.5 & 12.0 & 45.9 & 15.2 \\
\hline 49 & 19.3 & 15.2 & 32.3 & 23.2 \\
\hline Average & 10.0 & & 31.6 & \\
\hline SD & 10.5 & & 19.9 & \\
\hline
\end{tabular}



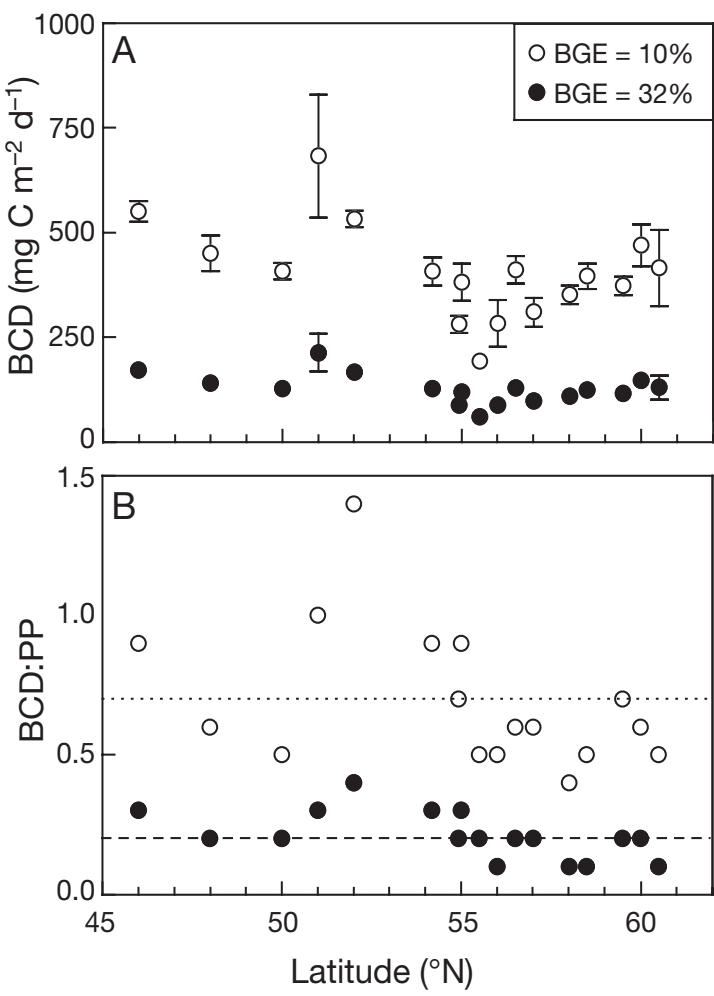

Fig. 6. (A) Bacterial carbon demand (BCD) and (B) the ratio of $\mathrm{BCD}$ to primary production (BCD:PP). BCD was calculated using the average growth efficiency measured in the light $(10 \%)$ and in the dark $(32 \%)$. The dotted line indicates the average BCD:PP ratio calculated using the light BGE estimate and the dashed indicates the average $\mathrm{BCD}: \mathrm{PP}$ ratio calculated using the dark BGE estimate

plankton stocks were higher (4 to $5 \mathrm{~g} \mathrm{C} \mathrm{m}^{-2}$ ) in the western North Atlantic during the bloom (Li et al. 1993).

Consequently, we expected higher bacterial biomass during NASB than found by NABE because of these differences in the timing of sampling relative to the bloom. Contrary to our expectation, bacterial biomass was lower during the NASB expedition than during NABE ( $t$-test, $\mathrm{p}<0.05$ ). The original analysis of the NABE data used a conversion factor of $20 \mathrm{fg} \mathrm{C} \mathrm{cell}^{-1}$ for estimating biomass from cell abundance (Lee \& Fuhrman 1987), which was the most reliable at the time. However, bacterial biomass was still higher during NABE than NASB when the same $12.4 \mathrm{fg} \mathrm{C} \mathrm{cell}^{-1}$ conversion factor (Fukuda et al. 1998) was applied to both data sets. Using the lower conversion factor, the integrated standing stock of bacteria during NABE was $1.10 \pm 0.28$ compared to $0.70 \pm 0.18 \mathrm{~g} \mathrm{C} \mathrm{m}^{-2}$ during NASB.

Like phytoplankton and bacterial biomass, rates of PP and BP were also higher in NABE (Ducklow et al. 2002) than in NASB. PP was $<2$-fold higher in NABE
(1084 $\left.\mathrm{mg} \mathrm{C} \mathrm{m}^{-2} \mathrm{~d}^{-1}\right)$ than in NASB $\left(610 \mathrm{mg} \mathrm{C} \mathrm{m}^{-2} \mathrm{~d}^{-1}\right)$, whereas BP was about 3-fold higher. BP averaged $140 \mathrm{mg} \mathrm{C} \mathrm{m}^{-2} \mathrm{~d}^{-1}$ (range 65 to $210 \mathrm{mg} \mathrm{C} \mathrm{m}^{-2} \mathrm{~d}^{-1}$ ) during NABE based on leucine incorporation and the same leucine conversion factor that we used $\left(1.5 \mathrm{~kg} \mathrm{C} \mathrm{mol}^{-1}\right)$, and during NASB it was $39 \mathrm{mg} \mathrm{C} \mathrm{m}^{-2} \mathrm{~d}^{-1}$ (range 20 to $69 \mathrm{mg} \mathrm{C} \mathrm{m}^{-2} \mathrm{~d}^{-1}$ ). When calculated with these production numbers, the BP:PP ratio was also significantly higher in NABE than in NASB $(0.14 \pm 0.05[\mathrm{SD}], \mathrm{n}=12$, and $0.07 \pm 0.03, \mathrm{n}=17$ in NABE and NASB, respectively; Student's $t$-test, $\mathrm{p}<0.01$ ). Current models of bacteria-phytoplankton interactions led us to expect that the BP:PP ratio would be higher during NASB (post-bloom) than during NABE (spring bloom), in contrast to what was observed. However, these ratios could vary for several reasons, given that NABE and NASB differed in many respects in addition to the timing of sampling during the spring to summer transition.

The BP:PP ratios of both studies can be evaluated by combining these data with BGE estimates. As already discussed by Ducklow et al. (2002), many of the original BP:PP estimates of Ducklow et al. (1993), when coupled with the BGE of $5 \%$ measured during NABE (Kirchman et al. 1991), require organic carbon inputs in addition to contemporaneous PP; even the BP:PP average given above $(0.14)$, which uses the lowest possible leucine conversion factor, implies that $\mathrm{BCD}$ greatly exceeded PP during NABE (BCD:PP $=0.14$ / $0.05=2.8$ ). However, there are fewer problems reconciling PP and BP estimates during NABE when our estimates of BGE are used. These BGE estimates, which averaged 10 and $32 \%$ in the light and dark, respectively, bracket the BGE average for the oceans $(15 \%)$ (del Giorgio \& Cole 1998).

There are even fewer problems in justifying BP:PP and BGE values in our study during NASB. Even assuming the low BGE of $10 \%$ measured in light incubations, on only 1 out of 17 occasions did BCD exceed PP during NASB. Our estimates of PP and BP, along with BGE, are also consistent with food-web models that take on different values for the excretion of dissolved organic matter (DOM) by phytoplankton and zooplankton (see Fig. 5 in Ducklow et al. 2002). Contemporaneous PP appeared sufficient to support BCD during the post-bloom conditions sampled during NASB.

Many of the conclusions just discussed, such as those based on correlations or levels of variability, are not sensitive to the values chosen for the conversion factors. In all cases, the factors used here are conservative and do not substantially affect our conclusions. For example, the leucine conversion factor used here is the lowest possible theoretical factor because it assumes that isotope dilution is zero. Using the conversion factor that assumes 2-fold isotope dilution (Simon \& Azam 
1989) would increase the calculated BCD proportionally. When this estimate of BP is considered together with the low BGE estimate measured in the light, then PP falls short of BCD on 10 out of 17 occasions. Of course, this is an extreme scenario that compares liberal estimates of BCD with estimates of PP that do not include possible extracellular release of fixed carbon. Similarly, we took the conservative approach by choosing the same conversion factor for the carbon content of AAP bacteria and for the rest of the heterotrophic prokaryotes, even though the cell size of AAP bacteria can be larger than that of other prokaryotes measured after DAPI staining (Sieracki et al. 2006). Incorporating an even larger value for carbon per cell for AAP bacteria would only strengthen our conclusion that AAP bacteria made up a substantial fraction of bacterial biomass.

Data on the diversity and abundance of AAP bacteria (Cottrell et al. 2006, Sieracki et al. 2006, Waidner \& Kirchman 2007) and of proteorhodopsin-containing bacteria (Béjà et al. 2001, Sabehi et al. 2005, Campbell et al. 2008) suggest that photoheterotrophy may be an important feature of microbial metabolism in the ocean. Our results indicate that in the Northeast Atlantic, AAP bacterial biomass was equivalent to that of Synechococcus sp., whereas in the Mid-Atlantic Bight, AAP bacterial abundance was as much as 10fold higher than Synechococcus sp. and 2-fold higher than Prochlorococcus sp. abundance (Cottrell et al. 2006). In the highly oligotrophic waters of the South Pacific Ocean, AAP bacteria were about half as abundant as Prochlorococcus sp. but were more abundant than Synechococcus sp. (Grob et al. 2007a,b, Lami et al. 2007).

It is still unknown what environmental conditions determine the abundance of AAP bacteria. Light probably plays a role because AAP bacteria are more abundant in the photic zone than below the sunlit portion of the water column (Cottrell et al. 2006). However, other factors probably are important because light does not explain why in the Northwest Atlantic AAP bacteria were 5-fold more abundant in October than in March (Sieracki et al. 2006). It is also unclear why AAP bacterial abundance can be so high in estuaries, such as the Chesapeake Bay and the Delaware estuary (Schwalbach \& Fuhrman 2005, Waidner \& Kirchman 2007). The abundance of AAP bacteria also differs among coastal regions (Schwalbach \& Fuhrman 2005).

The effects of light on bacterial growth and respiration are complex and have varied among studies, as illustrated by NASB work (the present study and Michelou et al. 2007) and results from South Florida (Pakulski et al. 1998). In South Florida waters, light inhibited bacterial growth, whereas growth in the light and in the dark was not different in the present study. BP in
NASB was higher in the light in waters sampled between Florida and the Azores but there was no difference in waters north of the Azores (Michelou et al. 2007). The results probably diverged because of the different waters sampled and also in part because of variation in experimental procedures. The Florida study used quartz bottles, which allow UV penetration, and Pakulski et al. (1998) measured BP using thymidine and leucine incorporation, whereas UV was excluded from the NASB experiment and growth was determined from changes in cell number (the present study). Furthermore, the influence of light on leucine incorporation during NASB varied, from $20 \%$ inhibition to $200 \%$ stimulation (Michelou et al. 2007). This variation in the effects of light was due in part to variation in the abundance of cyanobacteria and other potential photoheterotrophs (Michelou et al. 2007), including those with proteorhodopsin (Campbell et al. 2008).

In contrast to the effect on growth, the effect of light on microbial respiration was similar in Florida waters (Pakulski et al. 1998) and in the Northeast Atlantic examined by NASB (the present study). In both environments, oxygen consumption was higher and BGE was lower in the light than in the dark. These data suggest that growth in the light can have a higher metabolic cost, requiring greater DOM consumption and energy generation, perhaps to support the repair of light-induced damage. DNA damage caused by UV was probably one type of damage responsible for the light effect in the Pakulski et al. (1998) study, which used UV-transparent bottles. However, UV light was mostly excluded from the NASB incubations.

There is some evidence for non-UV light affecting bacterial metabolism. Hernández et al. (2006) observed that solar radiation inhibits BP and bacterial growth rates in surface and subsurface waters of the Chilean upwelling system. This inhibition was mainly caused by photosynthetically active radiation (PAR), followed by UV-A (320 to $400 \mathrm{~nm}$ ) and UV-B (280 to $320 \mathrm{~nm}$ ). Inhibition of $\mathrm{BP}$ ranged from 49 to $53 \%$ for PAR, 13 to $30 \%$ for UV-A and 5 to $14 \%$ for UV-B. These experiments suggest that light other than UV influences bacterial growth in the sunlit layers of the ocean. Although the effects of UV are well known, possible mechanisms underlying inhibitory effects of PAR remain obscure. Laboratory results indicate that exposure to PAR can damage nutrient uptake systems of enteric bacteria (Muela et al. 2000). The underlying mechanism of the damaging PAR effect has not been identified.

In contrast, the potential positive effects of PAR seem clear for presumed photoheterotrophic microbes like AAP bacteria and proteorhodopsin-containing bacteria. However, positive effects may not have been 
apparent in communities where the overall effect is a reduction in growth efficiency. Few data demonstrate any effect on known photoheterotrophic microbes (Giovannoni et al. 2005, Schwalbach et al. 2005, Gomez-Consarnau et al. 2007). The decrease in growth efficiency revealed by our study and by others suggests that light harvesting may incur a cost, such as possible photoinhibition if the harvested light energy is not properly coupled to energy-conserving reactions such as ATP generation. There is much work to be done to understand the range of possible beneficial and detrimental effects of light on marine bacteria.

Our results may not reflect the overall effect of light on bacteria, because the water was filtered to remove larger organisms such as phytoplankton and grazers, which are important sources of regenerated nutrients. Inorganic $\mathrm{N}$ and $\mathrm{P}$ were added to the bottles to compensate for any possible reduction in inorganic nutrients resulting from the removal of grazers (Obernosterer et al. 2003), but it was not feasible to make up for DOM potentially supplied by phytoplankton and other larger organisms (Nagata 2000). Therefore, we could have missed a light-mediated increase in bacterial growth driven by the response of bacteria to release of labile substrates by larger organisms (Ziegler \& Benner 2000). The bacteria in our incubations had access to only the existing DOM pool, whereas bacteria in situ could also take up DOM contemporaneously produced by phytoplankton and grazers. Nevertheless, lower growth efficiency in the light indicated greater metabolic demand and higher DOM consumption, even when fresh DOM production is not considered.

We expected that variation in respiration might be greater in the light than in the dark, because of variation in the abundance of photoheterotrophic microbes. In fact, the variability in respiration in the light was about half of that in the dark. Respiration in the light varied 4 -fold with a coefficient of variation of $64 \%$, versus 25 -fold with a coefficient of variation of $102 \%$ in the dark. In comparison, over an entire annual cycle, respiration in the nearby North Sea varied only 2-fold (Reinthaler \& Herndl 2005). More data are needed to assess the effect of light on seasonal variability of respiration, especially at high latitudes that experience extremes in day length.

Improved estimates of bacterial metabolism in the ocean are essential for understanding the marine carbon cycle because bacteria play a major role. The uncertainties about $\mathrm{BCD}$ and metabolic balance remaining after the conclusion of NABE persist today, although several studies have extended our knowledge, documenting instances of net heterotrophy and net autotrophy in this region of the Atlantic (Hoppe et al. 2002, Morán et al. 2004). The NASB results indicated net autotrophy even for the higher estimates of
BCD calculated using the lower BGE of $10 \%$. Even though the effect of light on BGE was not sufficient to shift the metabolic balance, the carbon flux through bacteria was 3-fold higher in the light than in the dark. Such a large light effect on carbon cycling by bacteria warrants further assessment in the Northeast Atlantic and elsewhere in the oceans.

Acknowledgements. Support for this project was provided by grants from the National Science Foundation (OCE-0452377 and MCB-0453993). We thank our NASB colleagues for their support during the Florida-Azores-Iceland expedition.

\section{LITERATURE CITED}

Béjà $\mathrm{O}$, Spudich EN, Spudich JL, Leclerc M, DeLong EF (2001) Proteorhodopsin phototrophy in the ocean. Nature 411:786-789

Campbell BJ, Waidner LA, Cottrell MT, Kirchman DL (2008) Abundant proteorhodopsin genes in the North Atlantic Ocean. Environ Microbiol 10:99-109

Campbell L (2001) Flow cytometric analysis of autotrophic picoplankton. In: Paul JH (ed) Methods in microbiology, Vol 30. Academic Press, San Diego, CA, p 317-343

Carlson CA, Bates NR, Ducklow HW, Hansell DA (1999) Estimation of bacterial respiration and growth efficiency in the Ross Sea, Antarctica. Aquat Microb Ecol 19:229-244

Cole JJ, Findlay S, Pace ML (1988) Bacterial production in fresh and saltwater ecosystems: a cross-system overview. Mar Ecol Prog Ser 43:1-10

Cooney MJ, Johnston WA, Pohl S, Bidigare RR (2006) Influence of photoperiod on pigmentation and metabolic efficiency of the marine aerobic anoxygenic photosynthetic bacterium Erythrobacter longus strain NJ3Y. Aquat Microb Ecol 43:303-309

Cottrell MT, Kirchman DL (2003) Contribution of major bacterial groups to bacterial biomass production (thymidine and leucine incorporation) in the Delaware estuary. Limnol Oceanogr 48:168-178

Cottrell MT, Mannino A, Kirchman DL (2006) Aerobic anoxygenic phototrophic bacteria in the Mid-Atlantic Bight and the North Pacific Gyre. Appl Environ Microbiol 72: 557-564

del Giorgio PA, Cole JJ (1998) Bacterial growth efficiency in natural aquatic systems. Annu Rev Ecol Syst 29:503-541

DiTullio GR, Geesey ME, Jones DR, Daly KL, Campbell L, Smith WO (2003) Phytoplankton assemblage structure and primary productivity along $170^{\circ} \mathrm{W}$ in the South Pacific Ocean. Mar Ecol Prog Ser 255:55-80

Ducklow HW, Harris RP (1993) Introduction to the JGOFS North Atlantic Bloom Experiment. Deep-Sea Res II 40:1-8

Ducklow HW, Kirchman DL, Quinby HL, Carlson CA, Dam HG (1993) Stocks and dynamics of bacterioplankton carbon during the spring bloom in the eastern North Atlantic Ocean. Deep-Sea Res II 40:245-263

Ducklow HW, Kirchman DL, Anderson TR (2002) The magnitude of spring bacterial production in the North Atlantic Ocean. Limnol Oceanogr 47:1684-1693

Fasham MJR (2003) Ocean biogeochemistry: a synthesis of the Joint Global Ocean Flux Study (JGOFS). Springer, New York

Fasham MJR, Boyd PW, Savidge G (1999) Modeling the relative contributions of autotrophs and heterotrophs to 
carbon flow at a Lagrangian JGOFS station in the Northeast Atlantic: the importance of DOC. Limnol Oceanogr 44:80-94

Fukuda R, Ogawa H, Nagata T, Koike I (1998) Direct determination of carbon and nitrogen contents of natural bacterial assemblages in marine environments. Appl Environ Microbiol 64:3352-3358

Geider RJ (1987) Light and temperature dependence of the carbon to chlorophyll a ratio in microalgae and cyanobacteria: implications for physiology and growth of phytoplankton. New Phytol 106:1-34

Giovannoni SJ, Bibbs L, Cho JC, Stapels MD and others (2005) Proteorhodopsin in the ubiquitous marine bacterium SAR11. Nature 438:82-85

Gómez-Consarnau L, González JM, Coll-Lladó M, Gourdon P and others (2007) Light stimulates growth of proteorhodopsin-containing marine Flavobacteria. Nature 445:210-213

Grob C, Ulloa O, Claustre H, Huot Y, Alarcon G, Marie D (2007a) Contribution of picoplankton to the total particulate organic carbon concentration in the eastern South Pacific. Biogeosciences 4:836-852

Grob C, Ulloa O, Li WKW, Alarcon G, Fukasawa M, Watanabe S (2007b) Picoplankton abundance and biomass across the eastern South Pacific Ocean along latitude 32.5 degrees S. Biogeosciences 332:53-62

Hernández KL, Quiñones RA, Daneri G, Helbling EW (2006) Effects of solar radiation on bacterioplankton production in the upwelling system off central-southern Chile. Mar Ecol Prog Ser 315:19-31

Hoppe HG, Gocke K, Koppe R, Begler C (2002) Bacterial growth and primary production along a north-south transect of the Atlantic Ocean. Nature 416:168-171

Kirchman DL (2001) Measuring bacterial biomass production and growth rates from leucine incorporation in natural aquatic environments. In: Paul JH (ed) Methods in microbiology, Vol 30. Academic Press, San Diego, CA, p 227-237

Kirchman DL, Suzuki Y, Garside C, Ducklow HW (1991) High turnover rates of dissolved organic carbon during a spring phytoplankton bloom. Nature 352:612-614

Koblizek M, Béjà O, Bidigare RR, Christensen S and others (2003) Isolation and characterization of Erythrobacter sp. strains from the upper ocean. Arch Microbiol 180:327-338

Kolber ZS, Van Dover CL, Niederman RA, Falkowski PG (2000) Bacterial photosynthesis in surface waters of the open ocean. Nature 407:177-179

Lami R, Cottrell MT, Ras J, Ulloa O, Obernosterer I, Claustre H, Kirchman DL, Lebaron P (2007) High abundances of aerobic anoxygenic photosynthetic bacteria in the South Pacific Ocean. Appl Environ Microbiol 73:4198-4205

> Lee S, Fuhrman JA (1987) Relationships between biovolume and biomass of naturally derived marine bacterioplankton. Appl Environ Microbiol 53:1298-1303

Li WKW, Dickie PM, Harrison WG, Irwin BD (1993) Biomass and production of bacteria and phytoplankton during the spring bloom in the western North Atlantic Ocean. DeepSea Res II 40:307-327

> Lochte K, Ducklow HW, Fasham MJR, Stienen C (1993) Plankton succession and carbon cycling at $47^{\circ} \mathrm{N} 20^{\circ} \mathrm{W}$ during the JGOFS North Atlantic bloom experiment. Deep-Sea Res II 40:91-114

Maixandeau A, Lefevre D, Karayanni H, Christaki U and others (2005) Microbial community production, respiration, and structure of the microbial food web of an ecosystem in the northeastern Atlantic Ocean. J Geophys Res 110:C07S17, doi:10.1029/2004JC002694
Massana R, Gasol JM, Bjornsen PK, Blackburn N and others (1997) Measurement of bacterial size via image analysis of epifluorescence preparations: description of an inexpensive system and solutions to some of the most common problems. Sci Mar 61:397-407

Michelou VK, Cottrell MT, Kirchman DL (2007) Lightstimulated bacterial production and amino acid assimilation by cyanobacteria and other microbes in the North Atlantic Ocean. Appl Environ Microbiol 73:5539-5546

Moran MA, Miller WL (2007) Resourceful heterotrophs make the most of light in the coastal ocean. Nat Rev Microbiol 5:792-800

Morán XAG, Fernandez E, Perez V (2004) Size-fractionated primary production, bacterial production and net community production in subtropical and tropical domains of the oligotrophic NE Atlantic in autumn. Mar Ecol Prog Ser 274:17-29

- Muela A, Garcia-Bringas JM, Arana I, Barcina I (2000) The effect of simulated solar radiation on Escherichia coli: the relative roles of UV-B, UV-A, and photosynthetically active radiation. Microb Ecol 39:65-71

Nagata T (2000) Production mechanisms of dissolved organic matter. In: Kirchman DL (ed) Microbial ecology of the oceans. Wiley-Liss, New York, p 121-152

- Obernosterer I, Kawasaki N, Benner R (2003) P-limitation of respiration in the Sargasso Sea and uncoupling of bacteria from P-regeneration in size-fractionation experiments. Aquat Microb Ecol 32:229-237

Pakulski JD, Aas P, Jeffrey W, Lyons M, Von Waasenbergen L, Mitchell D, Coffin R (1998) Influence of light on bacterioplankton production and respiration in a subtropical coral reef. Aquat Microb Ecol 14:137-148

Parsons TR, Maita Y, Lalli CM (1984) A manual of chemical and biological methods for seawater analysis. Pergamon Press, Oxford

Porter KG, Feig YS (1980) The use of DAPI for identifying and counting aquatic microflora. Limnol Oceanogr 25:943-948

> Preen K, Kirchman DL (2004) Microbial respiration and production in the Delaware Estuary. Aquat Microb Ecol 37: 109-119

Reinthaler T, Herndl GJ (2005) Seasonal dynamics of bacterial growth efficiencies in relation to phytoplankton in the southern North Sea. Aquat Microb Ecol 39:7-16

Rodrigues R, Williams PJleB (2001) Heterotrophic bacterial utilization of nitrogenous and nonnitrogenous substrates, determined from ammonia and oxygen fluxes. Limnol Oceanogr 46:1675-1683

Sabehi G, Loy A, Jung KH, Partha R and others (2005) New insights into metabolic properties of marine bacteria encoding proteorhodopsins. PLoS Biol 3:1409-1417

Schwalbach MS, Fuhrman JA (2005) Wide-ranging abundances of aerobic anoxygenic phototrophic bacteria in the world ocean revealed by epifluorescence microscopy and quantitative PCR. Limnol Oceanogr 50: 620-628

Schwalbach MS, Brown M, Fuhrman JA (2005) Impact of light on marine bacterioplankton community structure. Aquat Microb Ecol 39:235-245

Sieracki ME, Gilg IC, Thier EC, Poulton NJ, Goericke R (2006) Distribution of planktonic aerobic anoxygenic photoheterotrophic bacteria in the northwest Atlantic. Limnol Oceanogr 51:38-46

Simon M, Azam F (1989) Protein content and protein synthesis rates of planktonic marine bacteria. Mar Ecol Prog Ser 51:201-213

Stingl U, Desiderio RA, Cho JC, Vergin KL, Giovannoni SJ (2007) The SAR92 clade: an abundant coastal clade of 
culturable marine bacteria possessing proteorhodopsin. Appl Environ Microbiol 73:2290-2296

Valiela I (2001) Doing science: design, analysis, and communication of scientific research. Oxford University Press, Oxford

Waidner LA, Kirchman DL (2007) Aerobic anoxygenic phototrophic bacteria attached to particles in turbid waters of the Delaware and Chesapeake Estuaries. Appl Environ Microbiol 73:3936-3944

Editorial responsibility: Craig Carlson, Santa Barbara, California, USA
Williams PJleB (1981) Incorporation of microheterotrophic processes into the classical paradigm of the planktonic food web. Kiel Meeresforsch 5:1-28

Ziegler S, Benner R (2000) Effects of solar radiation on dissolved organic matter cycling in a subtropical seagrass meadow. Limnol Oceanogr 45:257-266

Zubkov MV, Sleigh MA, Burkill PH, Leakey RJG (2000) Picoplankton community structure on the Atlantic Meridional Transect: a comparison between seasons. Prog Oceanogr 45:369-386

Submitted: July 6, 2007; Accepted: December 4, 2007

Proofs received from author(s): February 3, 2008 